\title{
PERSEPSI MASYARAKAT TERHADAP KEPALA DESA SEBAGAI PENGERAK POLITIK DI DESA TEHANG
}

\author{
Wiwik Suprapti \\ Fakultas IImu Sosial dan IImu Politik Universitas PGRI Palangka Raya \\ (email: wiwiksuprapti61@gmail.com) \\ Kristina Kisni \\ Fakultas IImu Sosial dan IImu Politik Universitas PGRI Palangka Raya
}

\begin{abstract}
Abstrak
Penelitian ini bertujuan: 1) Untuk mengetahui persepsi masyarakat desa Tehang terhadap peran kepala desa sebagai penggerak politik. 2) Untuk mengetahui peranan kepala desa sebagai penggerak politik terhadap tingkat partisipasi politik masyarakat Tehang.

Penelitian ini menggunakan metode penelitian deskriptif kualitatif. Data yang dikumpulkan adalah berupa kata-kata, gambar dan bukan merupakan data yang berbentuk angka-angka. Sehingga penelitian ini akan berisi kutipan-kutipan data untuk memberi gambaran dalam pengumpulan data dilakukan secara langsung melalui observasi, wawancara, cacatan lapangan dan dokumentasi.

Hasil penelitian: a) Kepala desa merupakan pimpinan elit lokal dan pimpinan masyarakat yang mempunyai pengaruh bagi masyarakat. Kedudukan kepala desa sulit terpisahkan dari politik, untuk mempertahankan kekuasaan dan kestabilan politik yang dijalankan diperlukan adanya dukungan dari masyarakat desa. Keterlibatan kepala desa sebagai penggerak politik masyarakat untuk memilih salah satu partai atau kandidat tertentu dengan memberikan berbagai janji pembangunan infrastruktur di Desa Tehang yang selama ini sangat didambakan masyarakat. Berbagai proyek pembangunan desa yang dijalankan kepala desa telah memberikan kontribusi yang besar bagi masyarakat, karena masyarakat dapat menikmati secara langsung pembangunan desa. b) Selain persepsi positif, ada juga persepsi negatif yang muncul di masayarakat Desa Tehang. Keterlibatan kepala desa sebagai penggerak politik masih dipandang sebagai hal yang negatif yang selalu mendapat sorotan dan perhatian di kalangan masyarakat, karena hal tersebut dinilai sesuatu hal yang tidak etis. keterlibatan kepala desa sebagai penggerak politik masyarakat dipandang tidak memberikan contoh yang baik bagi berlangsungnya demokrasi.
\end{abstract}

\section{Kata kunci : Persepsi Masyarakat, Kepala Desa}

\section{Pendahuluan}

Pengalaman kegagalan birokrasi menjalankan fungsi idealnya sebagai alat bagi pencapaian tujuan negara, yaitu memakmurkan dan keadilan masyarakat, di masa Orde Baru tentu saja menjadi pengalaman buruk yang harus diperbaiki

\section{Jurnal Sociopolitico}


di masa depan. Posisi birokrasi sebagai alat pelanggeng rezim haruslah ditinggalkan, dan dikembalikan ke posisi sejatinya sebagai alat sebagai pencapaian tujuan negara. Semenjak reformasi hingga kini, masih membaca arah birokrasi Indonesia belum sepenuhnya lepas dari politik dan kekuasaan. Setelah kemenangan dalam suatu pemilihan, para pemimpin partai politik mendukung pemenang pemilu justru melestarikan model-model lama, birokrasi Indonesia.

Kepala desa merupakan birokrat yang mempunyai kekuasaan tertinggi di tingkat desa. Kepala desa sangat berperan penting terhadap proses berjalannya pemerintahan desa menuju kesejahteraan masyarakat. Sosok kepala desa merupakan orang yang sangat dihormati di kalangan masyarakat. Selain sebagai pemimpin desa, kepala desa juga merupakan elit lokal yang sangat berpengaruh bagi masyarakat. Besarnya pengaruh kedudukan kepala desa terhadap masyarakat, sering menjadikannya sebagai panutan bagi masyarakat.

Dalam menjalankan tugasnya sebagai aparat pemerintah desa, sering terdapat kepala desa yang terlibat politik, dimana ia berperan sebagai penggerak politik masyarakat. Hal tersebut tentunya sangat bertolak belakang dengan jabatannya sebagai aparat pemerintahan yang diharapkan berlaku netral dalam politik. Dengan keterlibatan kepala desa dalam berpolitik tentunya akan menimbulkan berbagai macam persepsi di kalangan masyarakat. Masyarakat yang mempunyai latar belakang yang berbeda baik dalam pendidikan maupun cara berpikir akan mempunyai anggapan tersendiri terhadap keterlibatan kepala desa dalam politik.
Pemilihan umum tidak dapat terpisahkan oleh politik, karena pemilu merupakan alat kekuasaan untuk mencapai tujuan bersama. Pesta demokrasi yang berlangsung di Indonesia mulai dari PILKADA, pemilu legislatif dan pemilihan Presiden secara langsung merupakan gambaran dari berjalannya sistem demokrasi di negara ini. Meskipun demikian proses demokrasi selama ini belum sepenuhnya menggambarkan masyarakat paham akan arti demokrasi. Masyarakat desa yang rata-rata masih berpendidikan rendah memahami politik hanya sebatas pesta rakyat yang dilakukan setiap lima tahun, dan tidak sedikit partisipasi politik yang dilakukan masyarakat masih dipengaruhi oleh adanya gerakan-gerakan dari pihak-pihak yang berkuasa. Budaya berpolitik, para elit politik yang suka memobilisasi massa dan menggunakan cara - cara kekerasan dan politik yang jauh dari etika politik harus segera dihilangkan. Masyarakat desa harus bisa melakukan partisipasi politik dengan dasar pemahaman yang jelas akan prinsip - prinsip demokrasi. Kini sudah saatnya euphoria politik masa Orde Baru diganti dengan budaya politik yang sehat, rasional, sebagai budaya antithesis dari budaya berpolitik yang penuh kepentingan.

Dalam budaya Jawa khususnya pada masyarakat pedesaan masih sangat besar rasa penghormatan kepada pejabat, budaya-budaya feodal masih berlangsung dikalangan masyarakat. Sehingga tidak sedikit masyarakat menjadikan pejabat sebagai panutan dalam pengambilan keputusan politik. Masyarakat akan melakukan apapun yang diperintahkan dengan rasa loyalitas yang tinggi. Meskipun demikian,

\section{Jurnal Sociopolitico}


juga terdapat pihak lain yang tidak setuju akan perilaku pejabat tersebut, hal tersebut dilatarbelakangi oleh pendidikan yang telah diperolehnya. Faktor pendidikan akan berpengaruh besar pada seseorang dalam berpikir dan melakukan tindakan. Sehingga akan berpengaruh pada persepsi tersendiri terhadap keterlibatan kepala desa dalam politik.

Demokrasi merupakan alat menuju tercapainya kesejahteraan dan keadilan bagi seluruh rakyat Indonesia yang merupakan cita-cita bangsa Indonesia selama ini, untuk mewujudkanya diperlukan komitmen bersama antara para biroktrat dan rakyat. Tidak seharusnya politik dijadikan oleh para elit politik hanya sebagai sarana untuk mencari kekuasaan dan kekayaan pribadi maupun kelompok yang menjadikan semakin jauhnya kesejahteraan bagi masyarkat dan hanya menjadikanya bayangan semu.

Kehadiran partai politik dalam pemerintahan membawa pengaruh besar terhadap kehidupan birokrasi pemerintahan. Salah satu pengaruh itu adalah birokrasi pemerintahan terkontaminasi terhadap bermacam dan beragam perbedaan ideologi yang dibawa oleh partai politik. Maka apabila kita amati perjalanan birokrasi kita, maka netralitas birokrasi pemerintah dari pengaruh dan kekuasaan partai politik belum pernah terwujud. Seringkali para birokrat terjun dalam kancah politik, hal tersebut akan menimbulkan hal yang tidak etis manakala birokrat yang bertugas sebagai pelayan administrasi masyarakat juga terlibat kancah politik. Sehingga masyarakat kurang mendapatkan layanan secara adil dan merata, sebagaimana fungsi dan tugas dari birokrasi tersebut.

Salah satu pencapaian demokrasi, akan dapat terwujud melalui reformasi birokrasi dan pendidikan politik bagi semua kalangan, sehingga politik tidak dijadikan sarana untuk kepentingan kelompok tertentu melainkan untuk kesejahteraan dan keadilan bagi seluruh rakyat Indonesia. Pembaharuan birokrasi merupakan usaha yang lebih mendasar dan menyeluruh yang menyangkut orientasi dan wawasan para penyelenggara, cara pendekatan, struktur dan mekanisme penyelenggaraan. Pembaharuan birokrasi merupakan usaha jangka panjang yang baru diharapkan hasilnya dalam kurun waktu satu generasi, yang didasari oleh kemauan politik yang tinggi serta penanganan yang konsisten dan sungguh-sungguh.

Dalam masyarakat madani, lembaga rakyat diakui keberadaannya dan peranannya sebagai penentu dan pengontrol kebijakan masyarakat. Ciri ciri yang melekat pada masyarakat madani bersumber pada demokrasi. Demokrasi mempunyai predikat beradaban, pemberdayaan kepada rakyat dan kemandirian. Demokrasi merupakan kekuasaan yang ada pada rakyat yang merupakan modal utama bagi rakyat.

Berdasarkan latar belakang di atas, maka dapat diidentifikasikan permasalahan sebagai berikut: Pertisipasi keterlibatan kepala desa sebagai penggerak politik bagi masyarakat.

\section{Metode Penelitian}

Dalam suatu penelitian, diperlukan adanya pendekatan penelitian. Penelitian ini menggunakan metode penelitian deskriptif kualitatif. Data yang dikumpulkan adalah berupa kata-kata, gambar dan bukan merupakan data yang berbentuk angka-angka. Sehingga 
penelitian ini akan berisi kutipan-kutipan data untuk memberi gambaran dalam pengumpulan data dilakukan secara langsung melalui observasi, wawancara, cacatan lapangan dan dokumentasi.

\section{Hasil dan Pembahasan}

\section{Partisipasi Politik Kepala Desa}

Kepala desa sebagai warga negara mempunyai hak untuk berpartisipasi politik. Keterlibatan dalam partisipasi politik, merupakan cara untuk mempengaruhi kebijakan pemerintah pusat. Melalui partisipasi politik kepala desa dapat aktif dalam mempengaruhi kebijakan pemerintah. Sebagai warga Negara maupun sebagai pejabat pemerintah, partisipasi politik yang dilakukan oleh kepala desa mempunyai bentuk yang berbeda dengan masyarakat pada umumnya, dimana partisipasi politiknya tidak sekedar untuk mempengaruhi kebijakan pemerintah melainkan juga berfungsi sebagai penguat kekuasaan. Hal tersebut sangat diperlukan guna membentuk sebuah pemerintahan yang kuat dan stabil. Berbagai cara kepala kepala desa dalam berprtisipasi politik diantaranya.

a) Secara aktif ikut melakukan pemilu

Kegiatan partisipasi politik dengan melakukan pemberian suara dan semboyan-semboyan yang diberikan saat kampanye, termasuk didalamnya mencari dukungan - dukungan terhadap masyarakat. Untuk mendapatkan dukungan diperlukan pendekatanpendekatan terhadap masyarakat. Untuk mendapat dukungan masyarakat membentuk tim (botoh) bertugas berkampanye dengan memberikan berbagai informasi dan simbol politik berupa pemberian stiker atau gambar partai atau kandidat politik kepada masyarakat. Hal tersebut seperti diungkapkan At bahwa: " secara langsung belum mbak, tapi para botoh memberikan gambar taupun stiker partai atau kandidat politik tertentu".

Kampanye merupakan suatu bentuk dari partisipasi politik yang dilakukan kepala desa yaitu dengan berperan aktif ikut dalam melakukan kegiatan berpolitik. Kampanye politik dilakukan pada saat berlangsungnya pemilihan umum, baik pada saat berlangsungnya pemilihan parpol maupun PILKADA bupati maupun gubernur. Pada saat tersebut kepala desa mempunyai peran penting dalam memberikan berbagai informasi dan agenda - agenda politik dari partai ataupun calon kandidat bupati maupun gubernur. Dalam hal ini kepala desa mendekati masyarakat guna mempengaruhi partisipasi politik masyarakat.

b) Melakukan lobbying atau lobi

Kegiatan ini dilakukan dengan pendekatan-pendekatan terhadap para pejabat, dalam hal ini kepala desa melakukan lobi pada bupati. Pendekatan ini dimaksudkan untuk mencari dukungan dan mempengaruhi keputusan. Dukungan dari pejabat dan pelaku elit politik dapat memberi kontribusi bagi kelanggengan dan kekuatan pemerintahan. Kontribusi ini memberikan dampak positif bagi berjalannya pembangunan desa. Berbagai program pembangunan desa dengan mudah terlaksana, dan dengan cepat masyarakat dapat menikmati pembangunan. Pendekatan atau lobi politik terhadap bupati sudah berjalan dengan baik hal ini terbukti dengan berjalanannya berbagai kegiatan yang telah berlangsung di desa berupa diadakannya pertandingan sepakbola

\section{Jurnal Sociopolitico}


bupati cup yang dihadiri secara langsung oleh bupati dan dukungan dari kepala desa dalam pencalonan kembali bupati keperiode selanjutnya, melalui kampaye. Gambar serta baliho calon bupati terpasang disekitar rumah kepala desa, hal tersebut merupakan gambaran dukungan kepala desa yang begitu besar terhadap pencalonan kembali pak Singgih sebagai bupati pada periode kedua. Hubungan yang erat dengan para pejabat juga berfungsi sebagai alat untuk memperkuat kepentingan politik. Hal tersebut seperti diungkapkan saudara X5 bahwa: " setuju saja mbak, karena ikut-ikutan masyarakat saja. Misalkan pada pemilihan bupati saya ikut saja, kan masih dalam satu wilayah jadi orangnya jelas". Kedekatan hubungan antara kepala desa dan bupati sangatlah dekat, hal tersebut dapat terbukti pada pemilihan bupati 2015, kepala desa berperan aktif untuk kemenangan pak singgih sebagai bupati pada periode 2 kalinya. Lobi-lobi politik yang dijalankan kepala desa terhadap bupati tidak sekedar hanya sebagai partisipasi politik tetapi kedekatan politik dengan bupati berdampak pada pembagunan. Hubungan yang harmonis kepala desa dengan bupati dapat memberikan kemudahan bagi berjalannya pembangunan. Bupati sebagai pejabat tinggi, dapat memberikan dampak yang posistif bagi berjalannya proses pembangunan.

Partisipasi politik merupakan sikap yang menyangkut aspek sosial dan politik. Dengan ikut terlibat dalam partisipasi politik berarti kepala desa ikut aktif dalam kegiatan-kegiatan dalam mempengaruhi keputusan dan kebijakakan pemerintah. Partisipasi politik sangat diperlukan untuk mendukung berjalannya proses pembangunan. Melalui keikutsertaan dalam partisipasi akan menumbuhkan sikap yang aktif dalam proses pembuatan kebijakkan.

Kepala desa sebagai pemimpin atau kaum elit memiliki tugas membuat kebijakkan dan sekaligus mengarahkan perilaku masyarakat sebagai kekuatan politik untuk mencapai suatu tujuan yang telah ditetapkan. Perilaku politik kepala desa tentunya tidak lepas dari bagaimana interaksi yang terjalin selama ini. Faktor sosial politik dan latar belakang pendidikan yang berlangsung di desa, telah memberikan nilai- nilai dan sikap tradisonal. Partisipasi yang dilakukan kepala desa adalah upaya untuk mencari dukungan guna mencari nilai-nilai khusus. Nilai nilai khusus dan kepentingan individu tersebut apabila tercapai, akan semakin mendorong partisipasi dalam politik.

Partisipasi politik yang dilakukan kepala desa merupakan sebuah partisipasi aktif yang dilakukan oleh kepala desa dalam mempengaruhi kebijakan pemerintah pusat melalui lobilobi politik guna memperkuat posisinya sebagai birokrat. Dukungan dari pejabat tinggi dinilai sebagai kekuatan untuk dapat mempertahankan sebuah kekuasaan, dimana dengan kedekatan antara kepala desa dan pejabat tinggi akan memberikan akses pelayanan yang mudah, sehingga program-program pembangunan akan berjalan dengan lancar.

c) Sosialisasi Politik Kepala Desa

Sebagai pimpinan desa, sosok kepala desa mempunyai peranan penting dalam mensosialisasikan politik kepada masyarakat. Melalui sosialisasi politik masyarakat dapat memperoleh pengetahuan dan pemahaman politik, yang diharapkan dapat menodorong tercapainya partisispasi politik bagi

\section{Jurnal Sociopolitico}


masyarakat. Proses sosialisasi politik berlangsung dalam masyarakat melalui berbagai informasi yang diberikan oleh kepala desa.

Sosialisasi politik berlangsung ketika berlangsungnya pemilian umum, dengan memberikan berbagai tatacara informasi dan bimbingan yang diberikan kepada masyarakat agar masyarakat ikut aktif dalam partisipasi politik. Sosialisasi politik merupakan proses bagaimana memperkenalkan sistem politik pada seseorang, dan bagaimana orang tersebut menentukkan tanggapan serta reaksinnya terhadap gejala-gejala politik. Sosialisasi politik ditentukan oleh lingkungan sosial, ekonomi dan kebudayaan itu berada.

Berlangsungnya sosialisasi politik sangat berkaitan dengan lingkungan dan pengalaman seseorang dimana lingkungan dan pengalaman akan mempengaruhi partisipasi politik seseorang. Bagi masyarakat desa yang sebagian besar adalah petani, akan memberikan suara politiknya dengan karakteristik pada partai politik yang dinilai lebih merakyat atau memperhatikan masyarakat atau kelompok-kelompok kecil khususnya para petani tani.

Pada masyarakat pedesaan, partisipasi politik yang dilakukan berdasarkan sosialisasi politik yang didapat berupa pengalaman dan nila-nilai yang telah didapat. Kepala desa sebagai agen sosialisasi politik secara langsung maupun tidak langsung, telah berusaha mensosialisasikan politik kepada masyarakat, dengan memberikan informasi tentang politik, yang diharapkan masyarakat dapat menerapkannya dalam sebuah tingkah laku.

Sosialisasi politik dapat berjalan dengan baik ketika nilai-nilai dapat diterima oleh masyarkat. Penerimaan suatu nilai dalam masyarakat akan terinternalisasikan dalam sebuah tingkah laku yang diharapkan menerapkannya dalam sebuah partisipasi politik. Lembaga pemerintahan desa mempunyai peranan penting sebagai agen sosialisasi politik dengan melakukan kontak langsung dengan masyarakat.

Tertanamnya nilai-nilai politik pada masyarakat sangat dipengaruhi, bagaimana individu tersebut menerima berbagai bentuk informasi yang telah diterimannya. Keberhasilan kepemimpinan kepala desa dalam melakukan berbagai program pembangunan, akan diterima oleh masyarakat sebagai nilai politik. Sosialisasi politik adalah proses yang berlangsung yang lama dan rumit yang dihasilkan dari usaha saling mempengaruhi diantara kepribadian individu dengan pengalaman-pengalaman politik yang relevan.

d) Interaksi kepala Desa Dengan Masyararakat

Kepala desa merupakan pimpinan desa yang bertugas sebagai pelayan bagi masyarakat. Sebagai sosok elit desa kepala desa dipandang oleh masyarakat mempunyai status sosial yang tinggi. Hubungan antara kepala desa dengan masyarakat terjalin melalui interaksi. Interaksi kepala desa dengan masyarakat yang berlangsung selama ini biasanya dilakukan pada saat masyarakat mengurusi pembuatan administrasi kependudukan misalkan pembuatan KTP, kartu keluarga, surat kelahiran maupun administrasi kependudukan lainnya. Sebagai birokrat yang bertugas melayani masyarakat, kepala desa mempunyai tugas memberikan pelayanan bagi setiap anggota masyarakat desa. Hal tersebut seperti diungkapkan oleh saudara X5

\section{Jurnal Sociopolitico}


bahwa: "Ya saya mengenal beliau, biasanya saya bertemu pak kepala desa pada saat pembuatan KTP, surat kelahiran ya pembuatan administrasi kependudukan. Selain itu saya tidak sering bertemu dengan beliau."

Bagi masyarakat desa kehadiran kepala desa sangat membantu bagi berlangsungnya proses administrasi kependudukan. Interaksi antara kepala desa dan warga masyarakat telah menimbulkan hubungan yang harmonis. Jalinan interaksi keduanya tidak hanya berjalanan pada saat melayani pembuatan administrasi kependudukan melainkan juga terjalin pada forum-forum kemasyarakatan. Kepala desa dijadikan sebagai sosok pemimpin yang diharapkan dapat memberikan arahan bagi masyarakat. Sehingga hampir pada setiap forum kemasyarakat kepala desa memberikan sambutan. Hubungan timbal balik antara individu dan kelompok masyarakat terlihat ketika kepala desa memberikan sambutan pada kegiatan kemasyarakatan, yaitu pada acara pengajian akbar maupun forum kajian keagamaan ( bukhori), pernikahan, maupun acara yang lainnya.

Dalam memberikan sambutannya kepada warga masyarakat, kepala desa sering juga menyampaikan kampanye politiknya, yaitu dengan memberikan janji- janji pembangunan kepada masyarakat untuk memenangkan kandidat atau partai tertentu. Pada saat jalan dusun belum diaspal, kepala desa menjanjikan pada warga untuk dapat memenangkan partai tertentu. Hal tersebut seperti diungkapkan oleh saudara X5 bahwa: "Kalau dari kepribadiannya pak kepala desa selalu meyapa masyarakat dan tidak membedakan rakyat kecil maupun orang besar".
Dalam interaksi dengan masyarakat, kepala desa dinilai sebagai sosok yang ramah, yaitu dengan selalu menyapa masyarakat dengan tidak memandang status sosial seseorang. Pola interaksi yang baik mempengaruhi hubungan timbal balik antara masyarakat dan kepala desa secara langsung. Adanya hubungan interaksi individu dengan kepala desa telah menimbulkan sebuah pemaknaan. Interaksi antara masyarakat dan kepala desa merupakan bentuk hubungan langsung antara penguasa dan rakyat. Dari interaksi yang berlangsung, akan membentuk suatu pemaknaan dalam masyarakat terhadap sosok kepala desa, dipandang dari kepribadiannya maupun kinerjanya.

\section{Persepsi Masyarakat Terhadap Kepala Desa Sebagai Penggerak Politik}

Keterlibatan kepala desa sebagai penggerak politik di Desa Tehang, telah menyebabkan keberagaman persepsi di kalangan masyarakat, hal tersebut didasarkan pada pemikiran masyarakat yang berbeda. Berdasarkan hasil wawancara dengan masyarakat setempat, penulis menemukan berbagai persepsi yang positif dan ada persepsi yang negatif.

\section{a) Persepsi Positif}

Kepala desa merupakan pimpinan elit lokal dan pimpinan masyarakat yang mempunyai pengaruh bagi masyarakat. Kedudukan kepala desa sulit terpisahkan dari politik, untuk mempertahankan kekuasaan dan kestabilan politik yang dijalankan diperlukan adanya dukungan dari masyarakat desa. Keterlibatan kepala desa sebagai penggerak politik masyarakat untuk memilih salah satu partai atau kandidat tertentu dengan memberikan berbagai janji pembangunan

\section{Jurnal Sociopolitico}


infrastruktur di Desa Tehang yang selama ini sangat didambakan masyarakat. Berbagai proyek pembangunan desa yang dijalankan kepala desa telah memberikan kontribusi yang besar bagi masyarakat, karena masyarakat dapat menikmati secara langsung pembangunan desa.

Salah satu anggota masyarakat yang bernama X5 mengatakan" Kalau dari kepribadiannya kepala desa merupakan sosok yang baik, yang selalu menyapa masyarakat, kalau dari segi pembangunan pak kepala desa sudah melakukan pemangunan infrastruktur desa, misalkan saja perbaikan jalan,penyediaan air bersih maupun bantuan peralatan RT."

Penilaian masyarakat akan keberhasilan kepemimpinan kepala desa sangat ditentukan sejaumana pembangunan itu berjalan. Sama halnya dengan saudari $\mathrm{X} 4$ yang berpendapat" Pak kepala desa telah membuat masyarakat jauh lebih baik mbak, yaitu mbak bisa terlaksanannya program pembangunan."

Keterlibatan kepala desa sebagai penggerak politik dinilai masyarakat tidak

menjadi masalah dan merupakan hal yang wajar karena kepala desa telah membawa masyarakat jauh lebih baik dibandingkan dengan kepemimpinan sebelumnya. Masyarakat desa sekarang dapat menikmati proyek pembangunan yang telah dijalankan oleh pemerintah. Salah satu warga masyarakat yang bernama X5 mengatakan" Selama saya tinggal disini, baru sekarang ini saya merasakan program pembangunan, dimana padamasa kepemimpinan sebelumnya yang belum terwujud."
Persepsi positif dikalangan masyarakat akan keterlibatan kepala desa sebagai penggerak politik merupakan respon positif dari masyarakat yang menganggap bahwa kepala desa sekarang ini telah memberi perubahan bagi masyarakat yang lebih baik.

b) Persepsi Negatif

Selain persepsi positif, ada juga persepsi negatif yang muncul di masayarakat Desa Tehang. Keterlibatan kepala desa sebagai penggerak politik masih dipandang sebagai hal yang negatif yang selalu mendapat sorotan dan perhatian di kalangan masyarakat, karena hal tersebut dinilai sesuatu hal yang tidak etis. keterlibatan kepala desa sebagai penggerak politik masyarakat dipandang tidak memberikan contoh yang baik bagi berlangsungnya demokrasi.

Persepsi seorang warga masyarakat yang bernama X1 berpendapat" Saya tidak setuju akan keterlibatan kepala desa sebagai penggerak politik karena hal tersebut kurang pantas, karena seharusnya kepala desa merupakan sosok yang bisa menyelenggarakan demokrasi yang baik di masyarakat, bukan mengajak masyarakatuntuk memilih partai atau kandidat tertentu untuk kepentingan politik tertentu."

Anggapan bahwa seharusnya kepala desa bersikap netral, di mana kepala desa tidak memihak golongan manapun, dan tidak seharusnnya berperan sebagai mobilisator politik masyarakat. Saudara X4 mengatakan bahwa" seharusnya kepala desa bersikap netral, tidak memihak kepentingan politik manapun karena kepala desa dipilih secara langsung oleh rakyat."

\section{Jurnal Sociopolitico}


Hal yang sama diutarakan oleh saudara X2 " sebagai kepala desa seharusnya tidak berpihak pada kepentingan politik manapun." Masyarakat yang tidak sependapat akan perilaku kepala desa sebagai penggerak politik akan memberikan respon negatif, karena masyarakat memandang bahwa perilaku tersebut, telah bertentangan dengan demokrasi.

Perilaku kepala desa sebagai penggerak politik bagi masyarakat merupakan stimulus atau rangsangan bagi munculnya pemikiran pendapat, Persepsi muncul, juga dipengaruhi oleh kondisi orang yang mempersepsikan. Masyarakat mempunyai persepsi yang beragam mengenai keterlibatan kepala desa sebagai penggerak politik masyarakat yang ada di Desa Tehang.

Masyarakat kadang mempersepsikan kedudukan kepala desa sebagai penggerak politik secara umum seperti elit-elit politik lain dan para birokrat lain yang lebih mementingkan kekuasaan dari pada kepentingan masyarakat. ketika masayarakat mempunyai pengalaman atau pengetahuan dari berbagai sumber baik melalui media ataupun dari masyarakat, bahwa para elit politik atau birokrat ketika melakukan berbagai janji pembangunan, merupakan janjijanji politikyang bertujuan menarik simpatik dari masyrakat yang bertujuan untuk mempertahankan kekuasaan.

Persepsi sebagai salah satu sumbangan pemikiran yang berasal dari masyarakat akan dapat mempengaruhi sikap. Label yang diberikan masyarakat pada elit politik masih buruk atau negatif, maka ada kecenderungan bahwa perilaku elit politik tidak beretika seperti yang telah dilabelkan pada kepada kepala desa. Mempersepsikan kepala desa sebagai penggerak politik masyarakat, dimana adannya kedua persepsi masing- masing mempunyai perasaan, kemampuan, harapan dan pengalaman yang berbeda akan dapat berpengaruh dalam seseorang mempersepsikan keterlibatan kepala desa sebagai penggerak politik.

\section{Kesimpulan}

1. Kepala desa merupakan pimpinan elit lokal dan pimpinan masyarakat yang mempunyai pengaruh bagi masyarakat. Kedudukan kepala desa sulit terpisahkan dari politik, untuk mempertahankan kekuasaan dan kestabilan politik yang dijalankan diperlukan adanya dukungan dari masyarakat desa. Keterlibatan kepala desa sebagai penggerak politik masyarakat untuk memilih salah satu partai atau kandidat tertentu dengan memberikan berbagai janji pembangunan infrastruktur di Desa Tehang yang selama ini sangat didambakan masyarakat. Berbagai proyek pembangunan desa yang dijalankan kepala desa telah memberikan kontribusi yang besar bagi masyarakat, karena masyarakat dapat menikmati secara langsung pembangunan desa.

2. Selain persepsi positif, ada juga persepsi negatif yang muncul di masayarakat Desa Tehang. Keterlibatan kepala desa sebagai penggerak politik masih dipandang sebagai hal yang negatif yang selalu mendapat sorotan dan perhatian di kalangan masyarakat, karena hal tersebut dinilai sesuatu hal yang tidak etis. keterlibatan kepala desa sebagai penggerak politik masyarakat

\section{Jurnal Sociopolitico}


dipandang tidak memberikan contoh yang baik bagi berlangsungnya demokrasi.

\section{Referensi}

Bahrent Sugihen.1997. Sosiolgi Pedesaan Suatu Pengantar. Jakarta: PT RajaGrafindo Persada.

Bimo Walgito.2002. Pengantar Psikologi umum. Yogyakarta: Penerbit Andi.

Burhan Bungin.2003.Penelitian Kualitatif. Jakarta:PT Raja Grafindo Persada.

Cholisin, dkk.2006. Dasar-Dasar Ilmu Politik.Yogyakarta: Bayu Indra Grafika.

Deddy Supriady. Dan Dadang Sholihin.2004. Otonomi Penyelenggaraan Pemerintahan Daerah. Jakarta: Gramedia Pustaka Utama.

Hamid Patilima.2007. Metode penelitian Kualitatif. Bandung: Alfabeta.

Hanif Nurcholis.2007. Pemerintahan dan Otonomi Daerah. Jakarta: Gramedia.

Haryatmoko.2003. Etika Politik dan Kekuasaan. Jakarta: Kompas

Hendra Nurtjahjo.2006. Filsafat Demokrasi. Jakarta: PT Bumi Aksara.

Zeitlin, Irving. Kembali Memahami Sosiologi. Yogyakata: Gadjah Mada University Press.

Lexy. J. Moleong. 2007. Metode Penelitian Kualitatif, Bandung: PT Remaja Roesdakarya.

Dimyati Mahmud.1990. Psikologi Suatu Pengantar. Yogyakarta: BPFE

Poloma Margaret.2007. Sosiologi Kontemporer. Jakarta: PT Grafindo Persada.

Mas'ud Said.2007. Birokrasi di Negara Birokratis. Malang: UMM Press.
Maswadi Rauf.2000. Konsensus Politik Sebuah penjaan Teoritis. Jakarta: Derektorat Jendaral Pendidikan Negeri Departemen Pendidikan Nasional.

Miftah Thoha. Birokrasi dan Politik di Indonesia. Jakarta: Raja Grafindo persada.

Rush, Michael dan Althoff Philip.2007. Pengantar Sosiologi Politik. Jakarta: PT Grafindo Persada.

Mohtar Mas'oed.1994. Politik, Birokrasi dan Pembangunan. Yogyakarta: Pustaka Pelajar.

Riswanda Imawan. 1998. Membedah Politik Orde Baru. Yogyakarta: Pustaka Pelajar Offside.

Ritzer, George dan Goodman J Douglas . 2005. Teori Sosiologi Modern. Jakarta:Prenada Media

Huntington, Samuel. Partisipasi Politik di Negara Berkembang. Jakarta:Rineka Cipta. .2003.Tertib Politik Pada Masyarakat Sedang Berubah.Jakarta: PT Grafindo Persada.

Sudiono Sastroatmojo.1995. Perilaku Politik.Semarang: IKIP Semarang Press

Soejdadi Djiwandono.1996. Revitalisasi Sistem Politik Indonesia, Jakarta: Center For Strategic and International Studies.

Soerjono Soekanto.2007. Sosiologi Suatu Pengantar. Jakarta: Grafindo Persada.

Timur Mahardika .2000. Gerakan Massa Mengupayakan Demokrasi dan Keadilan secara Damai,Yogyakarta: Lapera Pustaka Utama.

\section{Jurnal Sociopolitico}

